\title{
Perbuatan Melawan Hukum Terhadap Tindak Pidana Pengambilan Benda Bergerak Sebagai Objek Pembiayaan Leasing
}

\section{Action Against The Law Against Acting The Action of Moving Objects as a Leasing Financing Object}

\author{
Tito Alhafezt*, Triono Eddy \& Alpi Sahari \\ Program Magister Ilmu Hukum Fakultas Hukum, Universitas Muhammadiyah Sumatera Utara, \\ Indonesia \\ Diterima:03 Juli 2020; Disetujui: 02 Agustus 2020; Dipublish: 04 Agustus 2020 \\ *Email: titohafiezh71@gmail.com
}

\begin{abstract}
Abstrak
Asas perjanjian pacta sun servanda yang menyatakan bahwa perjanjian yang dibuat oleh pihak-pihak yang bersepakat, akan menjadi undang-undang bagi keduanya, tetap berlaku dan menjadi asa utama dalam hukum perjanjian. Tetapi terhadap perjanjian yang memberikan penjaminan fidusia dibawah tangan tidak dapat dilakuakan eksekusi. Proses eksekusi harus dilakuakn dengan cara menagajukan gugatan ke Pengadilan Negri melalui hukum acara yang normal hinggaq turunannnya putusan pengadilan. Tulisan ini bertujuan untuk mengeanalisis atau mengkaji pengaturan hukum perbuatan pengambilan benda bergerak sebagai objek pembiayaan leasing dan pertanggung jawaban pidana terhadap perbuatan pengambilan benda bergerak sebagai objek pembiayaan leasing. Hasil dari penelitian ini menunjukkan bahwa kebijakan pidana terhadap lembaga pembiayaan dalam eksekusi jaminan fidusia oleh debt collector yang sudah berpindah tangan berdasarkan undang-undang nomoir 42 tahun 199 tentang jaminan fidusia untuk menjamin kepastian hukum maka dibuat akata oleh notaris dan didaftarkan ke kantor fidusia. Penegakan hukum terhadap pihak leasing dalam penarikan jaminan fidusia oleh debt collector berdasarkan undanguundang nomor 42 tahun 1999 tentang fidusia menjelaskan hak eksekusi adalah kewenangan pengadiloan, bukan kewenangan penjual jasa penagih hutang yang biasanya disewa oleh pihak leasing.
\end{abstract}

Kata Kunci: Perbuatan Melawan Hukum, Tindak Pidana, Pengambilan Barang Bergerak, Objek Pembiayaan Leasing

Abstract
The principle of the pacta sun servanda agreement stating that the agreement made by the parties to the agreement, will be the law for both, remains in force and becomes the main hope in the law of the agreement. But the agreement that provides fiduciary guarantees under the hand cannot be executed. The execution process must be carried out by submitting a lawsuit to the Negri Court through normal procedural law so that the court's ruling decreases. This paper aims to analyze or examine the legal arrangements for the taking of movable objects as objects of leasing financing and criminal liability for the actions of taking movable objects as objects of leasing financing. The results of this study indicate that criminal policies against financial institutions in the execution of fiduciary guarantees by debt collectors who have changed hands under the law number 42 of 199 concerning fiduciary guarantees to ensure legal certainty are made akata by the notary public and registered with the fiduciary office. Law enforcement against leasing parties in withdrawing fiduciary collateral by debt collectors based on law number 42 of 1999 concerning fiduciary explains that the right of execution is the authority of the court, not the authority of the seller of debt collection services that are usually leased by the leasing party.

Keywords: Unlawful Acts, Criminal Acts, Taking of Movable Property, Objects of Leasing Financing

How to Cite: Alhafezt, T., Eddy, T., \& Sahari, A., (2020). Perbuatan Melawan Hukum Terhadap Tindak Pidana Pengambilan Benda Bergerak Sebagai Objek Pembiayaan Leasing. Journal of Education, Humaniora and Social Sciences (JEHSS). 3(1): 111-119. 


\section{PENDAHULUAN}

Pembangunan nasional diselenggarakan oleh masyarakat dan pemerintah, oleh karena itu peranan masyarakat dalam pembiayaan pembangunan harus ditumbuhkan dengan mendorong kesadaran, pemahaman dan penghayatan bahwa pembangunan adalah hak, kewajiban dan tanggungjawab seluruh rakyat, selanjutnya ditegaskan bahwa salah satu arah pembangunan jangka panjang dibidang ekonomi adalah untuk meningkatkan pengarahan dana-dana dalam negeri yang bersumber dari tabungan masyarakat, tabungan pemerintah dan penerimaan devisa.

Usaha peningkatan pengarahan dana-dana dalam negeri sangat ditentukan oleh peranan bank sebagai infra struktur pembangunan ekinomi. Maka dengan ini bank memiliki peranan yang banyak terhadap kehidupan masyarakat seperti melakukan pinjam-meminjam antara masyarakat dengan bank sesuai dengan jaminana yang diberikan (Maryanto, 1996). Begitu berkembangnya proses-proses kehidupan serta kejadian ditengah-tengah masyarakat, membuat hukum yang ada kewalahan mengejjar peristiwa hukum, terlebih diakibatkan oleh ekonomi, ada banyak cara manusia untuk memenuhi kebutuhannya, salah satunya dengan melakukan utang piutang, atau kredit dengan berbagai aspek hukum. apalagi dengan sistem legalitas, yang harus ada suatu peraturan baru seseorang pelaku peristiwa hukum dapat dijatuhi hukuman Siregar, R.J., Barus, U.M. \& Siregar, T. (2020).

Menurut undang-undang perbankan nomor 10 tahun 1998 kredit adalah penyedia uang atau tagihan yang dapat dipersamakan dengan itu, berdasarkan persetujuan atau kesepakatan pinjam meminjam melunasi hutangnya setelah jangka waktu tertentu dengan pemberian bunga, sedangkan pemberian pembiayaan adalah penyediaan uang uang atau tagihan yang dapat dipersamakan dengan itu, berdasarkan persetujuan atau kesepakatan antara bank dengan pihak lain yang mewajibkan pihak yang dibiayai untuk mengembalikan uang atau tagihan tersebut setelah jangka waktu tertentu dengan imbalan bagi hasil. Prolem pelaksanaan pemberian kredit yang dilakukan oleh bank harus hati-hati. Bank harus dapat bersikap bijak dalam memberikan pinjaman atau kredit kepada masyarakat sehingga dalam hal ini pihak bank harus memperhatikan prinsip-prinsip penyaluran atau pemberian kredit. Prinsip penyalura kredit adalah prinsip kepercayaan, tenggang waktu, degree of risk, resiko, prestasi/objek kredit. Indikator dari pemberian kredit ini adalah kepercayaan moral, komersial, financial, dan agunan (Muhammad: 1997).

Pemberian kredit kepada masyarakat dilakukan melalui suatu perjanjian kredit antara pemberi dengan penerima kredit sehingga terjadi hubungan hukum antar keduanya. Seringkali yang ditemui dilapangan perjanjian kredit dibuat oleh pihak kreditur atau dalam hal ini adalah bank, sedangkan debitur hanya mempelajari dan memahaminya dengan baik. Namun demikian perjanjian kredit ini perlu mendapat perhatian khusus dari kedua belah pihak dikarenakan perjanjian kredit mempunyai fungsi yang sangat penting dalam pemberian pengelolaan dan penatalaksanaan kredit, kesepakatan yang dilakuakn anatar debitur dengan kreditur, apabila debitur mendatangani perjanjian kreditur dianggap mengikat kedua belah pihak berlaku sebagai undang-undang bagi kedua belah pihak (Maryanto, 1996)

Salah satu kegiatan usaha perbankan adalah berupa pemberian kredit merupakan pemberian pinjaman uang oleh bank kepada anggota masyarakat yang umumnya disertai dengan penyerahan jaminan oleh debitur (pinjaman). Terhadap penerima jaminan kredit tersebut terkait dengan berbagai ketentuan hukum jaminan (Bahsan, 2015). Prakteksederhananya dalam jaminan fidusia adalah debitur pemilik barang menggunakan jaminan fidusia terhadap benda milik debitur dan dibuatkan akta notaris lalu didaftarkan ke kantor pendaftaran fidusia. Kreditur sebagai penerima fidusia akan mendaftar sertifikat fidusia dan salinannya diberikan kepada debitur. Dengan mendapat sertifikat jaminan fidusia maka kreditur fidusia serta merta mempunyai hak eksekusi langsung seperti yang terjadi dalam pinjam meminjam dalam perbankan. Kekuatan hukum sertifikat tersebut sama dengan putusan pengadilan yang sudah memiliki kekuatan hukum tetap. Sertifikat jaminan fidusia menimbulkan akibat hukum yang komplek dan beresiko karena kreditor dapat melakukan hak eksekusinya karena dianggap sepihak dan dapat menimbulkan kesewenang-wenangan dari kreditor. Apalagi eksekusi tersebut tidak melalui badan penilai harga 
yang resmi atau badan pelalang umum, tindakan tersebut dapat dikategorikan sebagai perbuatan melawan hukum, yang dlama hukum pidana, eksekusi objek fidusia dibawah tangan masuk dalam tindak pidana Pasal 368 KUHPidana jika kreditor melakukan paksaan dan ancaman perampasan. Berdasarkan hal inipenulis tertarik untuk melakuakn penelitian dengan judul Perbuatan melawan hukum terhadap tindak pidana pengambilan benda bergerak sebagai objek pembiayaan leasing di Polrestabes Medan.

\section{METODE PENELITIAN}

Metode yang digunakan dalam penelitian ini adala metode penelitian yudis normatif dengan pendekatan kualitatif (Ashshofa, 2010) dan penelitian ini bersifat yuridis empiris, yaitu suatu penelitian yang melakukan kajian terhadap penelitian lapangan dilakukanpenelitian langsung mengenai objek yang diteliti guna memperoleh bahan-bahan atau data yang konkrit mengenai perbuatan melawan hukum terhadap tindak pidana pengambilan benda bergerak sebagai objek pembiayaan leasing. Dimana sumber data primernya diperoleh dari informasi hasil wawancara responden dan informen seperti penyidik di Poltabes Medan. Sedangkan bahan hukum sekundernya dapat diproleh dari buku-buku dan tulisan-tulisan ilmiah hukum yang terkait dengan objek penelitian (Ali, 2009) serta dengan tambahan bahan hukum tersier yang memberikan petunjuk/penjelasan terhadap bahan hukum primer, sekunder seperti kamus, jurnal, majalah ensiklopedia (Amiruddin \& Asikin, 2013)

\section{HASIL DAN PEMBAHASAN}

\section{Pengaturan Hukum Perbuatan Pengambilan Benda Bergerak Sebagai Objek Pembiayaan Leasing}

Leasing lahir berdasarkan adanya suatu ikatan perjanjian. Menurut ketentuan pasal 1313 KUHPdt bahwa"perjanjian adalah suatu perbuatan dengan mana satu orang atau lebih mengikatkan dirinya kepada satu orang atau lebih lainnya". Lingkup perjanjian terlalu luas, mencakup juga perjanjian perkawinan yang diatur dalam bidang hukum keluarga. Padahal, yang dimaksud adalah hubungan antara debitor dan kreditor yang bersifat kebendaan. Perjanjian yang diatur dalam Buku III KUHPdt sebenarnya hanya melingkupi perjanjian bersifat kebendaan, tidak melingkupi perjanjian bersifat keorangan/personal. (Muhammad, 2011). Pengertian perjanjian yang disebutkan dalam pasal 1313 KUHPdt juga mempunyai arti yang luas dan umum sekali, tanpa menyebutkan untuk tujuan apa suatu perjanjian dibuat. Hanya menyebutkan tentang pihak yang satu atau lebih, mengikatkan dirinya pada pihak lainnya. Karrena itu suatu perjanjian akan lebih tegas artinya, jika pengertian perjanjian diartikan sebagai suatu persetujuan dimana dua orang atau lebih saling mengikatkan diri untuk melaksanakan suatu hal dalam bidang harta kekayaan (Syamsudin, 2005).

Subekti memberikan definisi "perjanjian" adalah suatu peristiwa dimana seorang berjanji pada seorang lain atau dimana dua orang itu saling berjanji untuk melaksanakan sesuatu hal. (Hernoko, 2010). Sedangkan KRMT Tirto diningrat memberikan definisi perjanjian adalah suatu perbuatan hukum berdasarkan kata sepakat di antara dua orang atau lebih untuk menimbulkan akibat-akibat hukum yang dapat dipaksakan oleh undang-undang.

Leasing adalah perjanjian yang berkenaan dengan kegiatan pembiayaan dalam bentuk penyediaan barang oleh lessor (pemberi sewa) untuk digunakan atau dimanfaatkan oleh lessee (penyewa) dalam jangka waktu tertentu berdasarkan pembayaran secara berkala. Dengan kata lain, leasing hakikatnya merupakan perjanjian sewa menyewa di mana lessor (pemberi sewa) menyerahkan barang untuk dimafaatkan oleh lessee (penyewa). Karena itu, leasing juga lazim disebut sebagai perjanjian sewa guna usaha (Subekti, 1997). Para pihak atau subjek dalam perjanjian leasing, umumnya antara perusahaan dengan perusahaan, tetapi dalam perkembangannya juga bisa terjadi antara perusahaan dengan seseorang sebagai subyek hukum pribadi. Objek leasing dapat berupa barang-barang bergerak seperti kendaraan bermotor, maupun barang tidak bergerak seperti mesin-mesin pabrik, dan lain-lain. Leasing diikat berdasarkan perjanjian baku atau kontrak standar, Menurut Munir Fuady, perjanjian baku adalah suatu 
perjanjian tertulis yang dibuat hanya oleh salah satu pihak, bahkan seringkali sudah tercetak dalam bentuk formulir-formulir yang dibuat oleh salah satu pihak, yang dalam hal ini ketika perjanjian tersebut ditanda tangani, umumnya para pihak hanya mengisi data-data informatif tertentu saja dengan sedikit atau tanpa perubahan dalam klausul-klausulnya, dimana pihak lain dalam perjanjian tersebut tidak mempunyai kesempatan atau hanya sedikit kesempatan untuk menegoisasi, mengubah klausula yang dibuat oleh salah satu pihak, sehingga biasanya perjanjian baku sangat berat sebelah. Demikian pula mengenai syarat-syarat baku dalam perjanjian yang masih akan dibuat, yang jumlahnya tidak tertentu, tanpa perlu merundingkan terlebih dahulu isinya. Maka perjanjian baku hakikatnya merupakan perjanjian yang didalamnya dibakukan syarat eksonerasi dan dituangkan dalam bentuk formulir (Fuady, 2002)

Debitur atau pemberi fidusia apabila cidera janji, eksekusi terhadap benda yang menjadi obyek jaminan fidusia sesuai aturannya dengan pelaksanaan penjualan objek jaminan fidusia tersebut dilakukan setelah lewat waktu 1 (satu) bulan sejak diberitahukan secara tertulis oleh pemberi dan penerima fidusia kepada pihak-pihak yang berkepentingan dan diumumkan sedikitnya dalam 2 (dua) surat kabar yang beredar di daerah yang bersangkutan. Pemberi fidusia wajib menyerahkan benda yang menjadi obyek jaminan fidusia dalam rangka pelaksanaan eksekusi jaminan fidusia. Dalam hal benda yang menjadi obyek jaminan fidusia terdiri atas benda perdagangan atau effek yang dapat dijual di pasar atau di bursa, penjualannya dapat dilakukan di tempat-tempat tersebut sesuai dengan peraturan perundang-undangan yang berlaku (Yahya, 2006)

\section{Pengaturan Hukum Perbuatan Pengambilan Benda Bergerak Sebagai Objek Pembiayaan Leasing}

Undang-Undang No. 42 Tahun 1999 tentang Jaminan Fidusia sudah berusia 20 tahun, Undang-Undang No. 42 Tahun 1999 tentang Jaminan Fidusia mempunyai peran yang sangat penting dalam menunjang pertumbuhan perekonomian Indonesia dan salah satu indicator getting credit. Saat ini, kata dia, jaminan fidusia yang bersifat accesoir merupakan landasan hukum terhadap perjanjian kredit, hal ini sangat memperhatikan kepentingan debitur dengan memberikan jaminan hukum kepada benda bergerak atau kendaraan yang di kredit dari kreditur (perusahaan pembiayaan). Jaminan yang lahir karena perjanjian adalah jaminan yang harus diperjanjikan terlebih dahulu diantara para pihak, yaitu perjanjian yang mengikuti dan melihat pada perjanjian dasar atau perjanjian pokok yang menerbitkan utang atau kewajiban atau prestasi bagi debitur terhadap kreditur. Pasal 14 ayat 3 Undang-Undang No. 42 Tahun 1999 tentang Jaminan Fidusia berbunyi jaminan lahir saat dilakukan pendaftaraan jaminan fidusia.

Pernyataan dalam Undang-Undang No. 42 Tahun 1999 tentang Jaminan Fidusia bisa dimaknai, apabila jaminan fidusia belum didaftarkan maka kreditur (perusahaan leasing/pembiayaan) belum memiliki hak jaminan fidusia termasuk hak untuk melakukan eksekusi terhadap benda yang sedang dijaminkan. Hal ini tentunya memberikan kepastian hukum dan perlindungan kepada para pihak melalui lembaga pendaftaran fidusia."Meski tujuan pengaturan lembaga jaminan khusus kebendaan (fidusia) utamanya guna melindungi kepentingan kreditur sebagai penyedia dana dalam perjanjian pinjam meminjam, namun ketentuan yang terdapat di Undang-Undang No. 42 Tahun 1999 tentang Jaminan Fidusia tetap memperhatikan kepentingan para pihak secara seimbang termasuk kepentingan debitur," jelasnya. Lembaga jaminan fidusia juga memberikan perlindungan kepada benda bergerak atau kendaraan yang sedang di kredit oleh debitur tidak bisa dieksekusi oleh kreditur kecuali dalam hal debitur wanprestasi. Kewenangan melakukan eksekusi baru bisa dilakukan oleh kreditur apabila debitur melakukan wanprestasi dengan memperhatikan Pasal 1238 Kitab Undang-Undang Hukum (KUH) Perdata.

Pasal 1238 KUH Perdata menyebutkan bahwa debitur dinyatakan lalai dengan surat perintah, akta sejenis atau berdasarkan kekuatan dari perjanjian akad kredit sendiri atau berdasarkan lewatnya waktu yang ditentukan dalam perjanjian. Dengan kata lain wanprestasi bisa diartikan debitur tidak melaksanakan kewajibannya kepada kreditur sesuai waktu yang sudah disepakati," katanya.Selain itu, tambah dia, Undang-Undang No. 42 Tahun 1999 tentang 象 http://mahesainstitute.web.id/ojs2/index.php/jehss 
Jaminan Fidusia tidak memberikan kewenangan kepada kreditur untuk melakukan upaya paksa atau mengambil benda yang menjadi objek jaminan fidusia secara paksa dari tangan debitur tanpa bantuan pihak berwenang seperti pengadilan atau kepolisian.Dalam rangka eksekusi fidusia, Kapolri sendiri sudah mengeluarkan Peraturan Kapolri No 8 Tahun 2011 tentang pengamanan eksekusi jaminan fidusia yang sudah berlaku sejak 22 Juni 2011. Undang-Undang No. 42 Tahun 1999 tentang Jaminan Fidusia memberikan kewenangan untuk melakukan eksekusi jaminan fidusia atas kekuasaannya sendiri atau melalui parate eksekusi seolah-oleh menjual barang miliknya sendiri, namun kewenangan tersebut tidak termasuk melakukan upaya paksa dalam hal debitur tidak secara sukarela menyerahkan benda objek jaminan yang dikuasainya dalam rangka eksekusi.

Untuk melakukan upaya paksa, Undang-Undang No. 42 Tahun 1999 tentang Jaminan Fidusiamemberikan alternatif bagi kreditur yang memerlukannya melalui pelaksanaan titel eksekutorial sebagaimana diatur dalam Pasal 29 ayat (1a) UU Jaminan Fidusia."Oleh karenanya tafsir yang salah terhadap ketentuan parate eksekusi tidak dapat dijadikan alasan untuk melakukan judicial review," jelasnya.Tak hanya itu, perlindungan lain yang diberikan Undang-Undang No. 42 Tahun 1999 tentang Jaminan Fidusia yakni larangan untuk memiliki benda yang menjadi objek jaminan dalam hal debitur wanprestasi. Hal ini sebagaimana diatur dalam Pasal 33 Undang-Undang No. 42 Tahun 1999 tentang Jaminan Fidusia. Berdasarkan ketentuan tersebut, objek jaminan hanya dimungkinkan untuk dijual atau dieksekusi jika debitur melakukan wanprestasi dan hasil penjualannya digunakan untuk melunasi kewajiban debitur jika ada sisa dari penjualan maka hasilnya harus dikembalikan kepada debitur.

Masyarakat perlu memahami bahwa alternatif pengadaan barang di atas memiliki konsekuensi hukum yang berbeda. Bila bentuk perjanjiannya berupa sewa-beli (hire-purchase), maka kewajiban konsumen dalam hal ini seolah-olah pemilik barang tersebut (misalnya: membayar pajak, mengganti kerusakan, biaya perawatan, dan lain-lain), namun harus membayar uang sewa sampai nantinya menjadi pemilik sesungguhnya setelah sewa terakhir dibayarkan. Selama masa sewa hak kepemilikan masih berada di tangan pihak yang menyewakan sehingga penyewa tidak boleh mengalihkannya ke tangan orang lain. Menurut Black's Law Dictionary, hirepurchase atau lease-purchase agreement adalah a rent-to-own purchase plan under which the buyer takes possession of the goods with the first payment and takes ownership with the final payment. (Henry,1979)

Sementara, Subekti melihat perjanjian sewa-beli lebih banyak unsur jual-belinya daripada unsur sewamenyewanya. Oleh sebab itu, perjanjian sewa-beli ini memiliki kemiripan dengan perjanjian leasing, yaitu financial lease. Dalam perjanjian leasing yang berupa financial lease, perusahaan pembiayaan (disebut lessor) menyewakan barang kepada lessee dengan membayar uang sewa dalam jangka waktu tertentu dengan opsi atau hak bagi lessee untuk memiliki barang tersebut dengan membayar nilai nominal barang yang terakhir. Namun,praktek leasing tersebut hanya tersedia untuk kebutuhan barang modal saja, bukan konsumsi. Selain leasing model financial lease, terdapat juga model operating lease yang merupakan sewa kegunaan barang saja, tidak untuk dimiliki. Dalam perjanjian leasing, pengguna obyek bukanlah pemilik barang sehingga ketika barang leasing dialihkan ke orang lain, pengguna dapat dikenakan pidana.

Perjanjian leasing melibatkan tiga pihak, yaitu penyedia/supplier barang,perusahaan pembiayaan yang menyediakan dana, serta penyewa/pengguna barang. Namundi Indonesia, berdasarkan Peraturan Menteri Keuangan Nomor 84/PMK. 012/2006 tentang Perusahaan Pembiayaan, perjanjian pembiayaan dapat melibatkan dua pihak saja, yaitu perusahaan pembiayaan dan penyewa/pengguna barang tersebut. Menurut Pasal 3 ayat 2 PMK tersebut, usaha leasing dapat dilakukan dengan membeli barang milik penyewa/pengguna barang dan kemudiandisewagunakan kembali kepada bekas pemiliknya. Jadi tidak hanya barang baru yang dapat disewakan, barang bekaspun boleh. Praktek leasing yang membeli barang milik penyewa dan kemudian menyewakannya kembali sebenarnya berupa pinjaman uang dengan memberikan barang jaminan. Hanya sajakonstruksi hukum berbeda, leasing dengan opsi beli berdasarkan akibat hukumnya hampir sama seperti sewa-beli. 
Berbeda dengan lembaga jual-beli secara kredit, di sinipengguna barang berlaku sebagai pemilik menurut titel jual-beli. Hanya saja pembayarannya dilakukan secara mencicil. Cicilan tersebut dianggap utang sehingga kalau barang tidak dijadikan sebagai jaminan, maka barang tidak dapat ditarik begitu saja tanpa melalui proses pengadilan. Namun, biasanya untuk perjanjian jual-beli kredit seperti ini, barang yang dibeli kemudian dijadikan jaminan. Lembaga jaminan yang digunakan adalah jaminan fidusia (FEO - Fiduciare Eigendom Overdracht). Jaminan fidusia memberikan keuntungan bagi pengguna, karena barang tak perlu diserahkan kepada perusahaan pembiayaan, cukup bukti kepemilikannya saja (kalau sepeda motor, berarti menyerahkan BPKBnya saja). Barang/obyek tetap dapat digunakan dan perusahaan pembiayaan dapat menarik barang jaminan tersebut kalau pengguna wanprestasi atau ingkar janji. Berdasarkan PMK No: 130/PMK.010/2012 tadi, maka tanpa jaminan fidusia (dan fidusia harus resmi didaftarkan), barang/obyek tidak dapat ditarik begitu saja oleh perusahaan pembiayaan.

Istilah pidana sering diartikan sama dengan istilah hukuman. Namun berkenaan dengan pembahasan saat ini penulis ingin memisahkan pengertian dari kedua istilah tersebut. Hukuman adalah suatu pengertian umum dan lebih luas, yaitu sebagai suatu sanksi yang tidak mengenakan yang sengaja ditimpakan kepada seseorang. Sedangkan pidana merupakan suatu pengertian khusus yang berkenaan dengan sanksi dalam hukum pidana. Walaupun ada juga persamaannya dengan pengertian umum, yaitu sebagai suatu sanksi yang berupa tindakan yang menderitakan atau suatu nestapa.Dalam bahasa Belanda kedua-duanya diberi istilah yang sama, yaitu "Straf" (Hamzah:1985)

Debt collector dengan sengaja atau ada maksud tujuan lain melakukan perampasan motor dijalan secara paksa terhadap nasabah dapat dijerat Pasal 368 ayat (1) KUHP berisi tentang "barangsiapa dengan maksud untuk menguntungkan diri sendiri atau orang lain dengan melawan hukum memaksa orang dengan kekerasan atau ancaman kekerasan supaya orang itu memeberikan suatu barang yang seluruhnya atau sebagian kepunyaan orang itu sendiri atau kepunyaan orang lain, atau supaya orang itu membuat hutang atau menghapuskan piutang, dihukum karena memeras dengan hukuman penjara selama-lamanya sembilan tahun."

\section{Pertanggungjawaban Pidana Terhadap Perbuatan Pengambilan Benda Bergerak Sebagai Objek Pembiayaan Leasing}

Konsepsi perbuatan melawan hukum dikenal dalam dimensi hukum perdata dan hukum pidana. Dari aspek etimologis dan terminologis maka perbuatan melawan hukum dalam bahasa Belanda dikenal dengan terminologi "wederrechtelijk" dalam ranah hukum pidana dan terminologi "onrechtmatige daad" dalam ranah hukum perdata. Akan tetapi, pengertian dan terminologi "wederrechtelijk" dalam hukum pidana tersebut ada diartikan sebagai bertentangan dengan hukum (in strijd met het recht), atau melanggar hak orang lain (met krenking van eens anders recht) dan ada juga yang mengartikan sebagai tidak berdasarkan hukum (niet steunend op het recht) atau sebagai tanpa hak (zonder bevoegheid). Unsur inilah yang terkandung dalam rumusan Pasal 372 KUHP. Kebijakan pidana terhadap lembaga pembiayaan (finance) dalam eksekusi jaminan fidusia oleh debt collector yang sudah berpindah tangan berdasarkan Undang- Undang Nomor 42 tahun 1999 tentang Jaminan Fidusia, menegaskan bahwa untuk menjamin kepastian hukum bagi kreditor maka dibuat akta yang dibuat oleh notaris dan didaftarkan ke Kantor Pendaftaran Fidusia. Nanti kreditor akan memperoleh sertifikat jaminan fidusia berirah-irah demi Keadilan Berdasarkan Ketuhanan Yang Maha Esa (Widjaja, \& Putra, 2019; Ardo, 2019; Pasaribu, dkk., 2019; Sipayung, dkk., 2019; Marpaung, dkk., 2016).

Dengan demikian, memiliki kekuatan hak eksekutorial langsung apabila debitor melakukan pelanggaran perjanjian fidusia kepada kreditor (parate eksekusi), sesuai Undang- Undang Nomor: 42 tahun 1999 tentang Jaminan Fidusia. Perjanjian fidusia yang tidak di buatkan akta notaris dan didaftarkan di kantor pendaftaran fidusia alias dibuat dibawah tangan. Pengertian akta di bawah tangan adalah sebuah akta yang dibuat antara pihak-pihak dimana pembuatanya tidak di hadapan pejabat pembuat akta yang sah yang ditetapkan oleh undang-undang (notaris, PPAT dan lain-lain). Akta di bawah tangan bukanlah akta otentik yang memiliki nilai pembuktian sempurna. Sebaliknya, akta otentik adalah akta yang dibuat oleh atau di depan pejabat yang ditunjuk oleh Undang-Undang dan memiliki kekuatan pembuktian sempurna. Untuk akta yang dilakukan di 
bawah tangan biasanya harus diotentikan ulang oleh para pihak jika hendak dijadikan alat bukti sah, misalnya di pengadilan. Pertanyaannya adalah apakah sah dan memiliki kekuatan bukti hukum suatu akta di bawah tangan? Menurut pendapat penulis, sah-sah saja digunakan asalkan para pihak mengakui keberadaan dan isi akta tersebut. Dalam prakteknya, di kampung atau karena kondisi tertentu menyebabkan hubungan hukum dikuatkan lewat akta di bawah tangan seperti dalam proses jual beli dan utang piutang. Namun, agar akta tersebut kuat, tetap harus dilegalisir para pihak kepada pejabat yang berwenang. Sementara itu penipuan diatur dalam Pasal 378 KUHP. Yaitu dengan maksud untuk menguntungkan diri sendiri atau orang lain secara melawan hukum, dengan memakai nama palsu atau martabat palsu, dengan tipu muslihat, ataupun rangkaian kebohongan, menggerakkan orang lain untuk menyerahkan barang sesuatu kepadanya, atau supaya memberi hutang maupun menghapuskan piutang. (Simanjuntak, 2009)

Benda yang tidak ada pemiliknya, baik sejak semula maupun telah dilepaskan hak miliknya tidak dapat menjadi objek penggelapan. Benda milik suatu badan hukum, seperti milik negara adalah berupa benda yang tidak/bukan dimiliki oleh orang, adalah ditafsirkan sebagai milik orang lain, dalam arti bukan milik petindak, dan oleh karena itu dapat menjadi objek penggelapan maupun pencurian. Orang lain yang dimaksud sebagai pemilik benda yang menjadi objek penggelapan, tidak menjadi syarat sebagai orang itu adalah korban, atau orang tertentu, melainkan siapa saja asalkan bukan petindak sendiri.

Berdasarkan konsepsi hukum pidana, eksekusi objek fidusia di bawah tangan masuk dalam tindak pidana Pasal 368 KUHPidana jika kreditor melakukan pemaksaan dan ancaman perampasan. Pasal ini menyebutkan "barang siapa dengan maksud untuk menguntungkan diri sendiri atau orang lain secara melawan hukum, memaksa seorang dengan kekerasan atau ancaman kekerasan untuk memberikan barang sesuatu, yang seluruhnya atau sebagian adalah kepunyaan orang itu atau orang lain, atau supaya membuat hutang maupun menghapuskan piutang, diancam karena pemerasan dengan pidana penjara paling lama sembilan bulan.

Ketentuan pasal 365 ayat kedua, ketiga, dan keempat berlaku bagi kejahatan ini. Situasi ini dapat terjadi jika kreditor dalam eksekusi melakukan pemaksaan dan mengambil barang secara sepihak, padahal diketahui dalam barang tersebut sebagian atau seluruhnya milik orang lain. Walaupun juga diketahui bahwa sebagian dari barang tersebut adalah milik kreditor yang mau mengeksekusi tetapi tidak didaftarkan dalam di kantor fidusia. Bahkan pengenaan pasal-pasal lain dapat terjadi mengingat bahwa dimana-mana eksekusi merupakan bukan hal yang mudah, untuk itu butuh jaminan hukum dan dukungan aparat hukum secara legal. Inilah urgensi perlindungan hukum yang seimbang antara kreditor dan debitor.

Proses eksekusi jaminan fidusial asas perjanjian pacta sun servanda yang menyatakan bahwa perjanjian yang dibuat oleh pihak-pihak yang bersepakat, akan menjadi undang-undang bagi keduanya, tetap berlaku dan menjadi asas utama dalam hukum perjanjian. Tetapi terhadap perjanjian yang memberikan penjaminan fidusia di bawah tangan tidak dapat dilakukan eksekusi. Proses eksekusi harus dilakukan dengan cara mengajukan gugatan perdata ke Pengadilan Negeri melalui proses hukum acara yang normal hingga turunnya putusan pengadilan. Inilah pilihan yang prosedural hukum formil agar dapat menjaga keadilan dan penegakan terhadap hukum materiil yang dikandungnya. Proses ini hampir pasti memakan waktu panjang, kalau para pihak menggunakan semua upaya hukum yang tersedia. Biaya yang musti dikeluarkan pun tidak sedikit. Tentu saja, ini sebuah pilihan dilematis. Dalih mengejar margin besar juga harus mempertimbangkan rasa keadilan semua pihak. Masyarakat yang umumnya menjadi nasabah juga harus lebih kritis dan teliti dalam melakukan transaksi. Sementara bagi Pemerintah, kepastian, keadilan dan ketertiban hukum adalah penting.

Kebanyakan Pengusaha Pembiayaan melakukan perjanjian leasing adalah sepihak baik pembuatnya, maupun isinya yang tidak seimbang (lebih menguntungkan pembuat draft) demi keuntungan yang sebesar-besarnya. Persoalannya karena tidak mau mengeluarkan biaya, waktu dan tenaga lebih (dari proses pembuatan harus di hadapan Notaris hingga pendaftaran akta). Debitur yang selalu berada diposisi yang lebih lemah (membeli secara leasing), tetapi pihak perusahaan selalu menggunakan cara-cara premanisme kepada debitur perjanjian 
pembayarannya macet. Saat ini, bemunculannya lembaga pembiayaan (finance) yang menyelenggarakan leasing perlu dicermati oleh para krediturnya. Lembaga pembiayaan ini pada umumnya menggunakan tata cara perjanjian yang mengikutkan jaminan fidusia bagi objek benda jaminan fidusia. Konsep dasar dari jaminan fidusia tersebut adalah: mobil yang dibeli oleh debitur tersebut "diserahkan kepemilikannya" kepada multifinance. Dengan diserahkannya kepemilikan atas mobil tersebut, maka debitur hanya bertindak selaku peminjam pakai. Oleh pihak multifinance, penyerahan kepemilikan tersebut di tuangkan dalam akta Jaminan Fidusia (dengan menggunakan kuasa untuk memfidusiakan), dan selanjutnya di daftarkan pada Kantor Pendaftaran Fidusia dimana debitur berdomisili. Setelah terbit sertifikat Jaminan fidusia, maka selama debitur tidak dapat melunasi kewajiban angsurannya, maka pihak multifinance berhak untuk sewaktu-waktu menarik mobil tersebut dari tangan debitur

Penarikan mobil seperti yang dialami oleh debitur tersebut sering sekali terjadi di dalam praktek. Karena hal tersebut seringnya memberikan dampak negative berupa bantahan, ataupun perlawanan di lapangan, maka Untuk mengamankan pelaksanaan eksekusi jaminan Fidusia, POLRI menerbitkan Peraturan Kepala Kepolisian Negara Republik Indonesia Nomor 8 Tahun 2011 Tentang Pengamanan Eksekusi Jaminan Fidusia yang berlaku sejak 22 Juni 2011. Tujuan di terbitkannya Peraturan Kepala Kepolisian Negara Republik Indonesia Nomor 8 Tahun 2011 Tentang Pengamanan Eksekusi Jaminan Fidusia adalah untuk menyelenggarakan pelaksanaan eksekusi jaminan fidusia secara aman, tertib, lancar, dan dapat dipertanggungjawabkan; melindungi keselamatan Penerima Jaminan Fidusia, Pemberi Jaminan Fidusia, dan/ atau masyarakat dari perbuatan yang dapat menimbulkan kerugian harta benda dan/ atau keselamatan jiwa.

Mengenai proses pengamanan eksekusi atas jaminan fidusia ini tercantum dalam Bab III mengenai permohonan pengamanan eksekusi Pasal 7 Peraturan Kepala Kepolisian Negara Republik Indonesia Nomor 8 Tahun 2011 Tentang Pengamanan Eksekusi Jaminan Fidusia, menegaskan bahwa dimana permohonan pengamanan eksekusi tersebut harus diajukan secara tertulis oleh penerima jaminan fidusia atau kuasa hukumnya kepada Kapolda atau Kapolres tempat eksekusi dilaksanakan. Pemohon wajib melampirkan surat kuasa dari penerima jaminan fidusia bila permohonan diajukan oleh kuasa hukum penerima jaminan fidusia, dengan melampirkan antara lain, Salinan akta jaminan fidusia, Salinan sertifikat jaminan fidusia, Surat peringatan kepada Debitor untuk memenuhi kewajibannya, dalam hal ini telah diberikan pada Debitor sebanyak 2 kali dibuktikan dengan tanda terima, Identitas pelaksana eksekusi, Surat tugas pelaksanaan eksekusi.

\section{SIMPULAN}

Pasal 1238 KUH Perdata menyebutkan bahwa debitur dinyatakan lalai dengan surat perintah, akta sejenis atau berdasarkan kekuatan dari perjanjian akad kredit sendiri atau berdasarkan lewatnya waktu yang ditentukan dalam perjanjian. Dengan kata lain wanprestasi bisa diartikan debitur tidak melaksanakan kewajibannya kepada kreditur sesuai waktu yang sudah disepakati," katanya.Selain itu, tambah dia, Undang-Undang No. 42 Tahun 1999 tentang Jaminan Fidusia tidak memberikan kewenangan kepada kreditur untuk melakukan upaya paksa atau mengambil benda yang menjadi objek jaminan fidusia secara paksa dari tangan debitur tanpa bantuan pihak berwenang seperti pengadilan atau kepolisian.Dalam rangka eksekusi fidusia, Kapolri sendiri sudah mengeluarkan Peraturan Kapolri No 8 Tahun 2011 tentang pengamanan eksekusi jaminan fidusia yang sudah berlaku sejak 22 Juni 2011.

Pertanggungjawaban Pidana Pihak Leasing dalam Penarikan Jaminan Fidusia oleh Debt Collector Berdasarkan Undang-Undang Nomor 42 Tahun 1999 tentang Jaminan Fidusia, menegaskan bahwa pengalihan kendaraan dalam masa pembayaran perjanjian pembiayaan leasing yang menyimpang dari isi perjanjian dapat dikualifikasikan sebagai tindak pidana penggelapan sebagaimana diatur Pasal 372 dan tiindak pidana penadahan sebagaimana diatur Pasal 480 KUHP apabila memenuhi unsur kedua Pasal KUHP dimaksud. Hal ini terkait dengan klausul perjanjian baku yang memberikan kebebasan kepada pihak Kreditor untuk mengajukan 
tuntutan-tuntutan hukum terhadap Debitor dihadapan pengadilan-pengadilan lain dimanapun juga yang dianggap baik oleh Kreditor sesuai dengan ketentuan hukum yang berlaku.

\section{DAFTAR PUSTAKA}

Abdulkadir, M., (2011). Hukum Perdata Indonesia, Bandung : PT Citra Aditya Bakti

Ali. Z. (2009). Metode Penelitian Hukum. Edisi 1 (satu), Cetakan Pertama. Jakarta: Sinar Grafika, 2009.

Amiruddin dan Asikin, Z. (2013). Pengantar Metode Penelitian Hukum. Edisi. Satu, Cetakan Ketujuh. Jakarta: Rajawali Pers.

Ardo, F.K. (2019). Analisis Hukum Perkara Jaminan Fidusia Dalam Putusan Pengadilan Negeri Padang Nomor 38/Pdt.G/2018/PN Pdg, Jurnal Ilmiah Penegakan Hukum, 6 (2) 2019: 96 - 101

Ashshofa, B, (2010). Metode Penlitian Hukum, Jakarta, Rineka Cipta.

Bahsan, m. (2015) , Hukum Jaminan dan Jaminan Kredit Perbankan Indonesia, Jakarta: Rajawali Pers,

Campbell, H. (19790. Black's Law Dictionary, Fifth Edition, St. Paul Minn West Publishing Co. USA,

Djumhana, M, (1997). Hukum Perbankan Indonesia, Bandung : Citra Aditya Bakti

Fuady, M, (2002). Hukum Tentang Lembaga Pembiayaan (Dalam Teori dan Praktek), Bandung, PT. Citra Aditya.

Hamzah, A (1995). Sistem Pidana dan Pemidanaan Indonesia dari Retribusi ke Reformasi, Pradnya Paramita, Jakarta.

Hernoko,A.Y. (2010). Hukum Perjanjian Asas Proporsionalitas dalam Kontrak komersial, Kencana Prenada Media Group.

Marpaung, B., Arifin. S., \& Hidayani, S (2016). Tinjauan Yuridis Akibat Hukum Terhadap Wanprestasi Dalam Perjanjian Kredit(Studi Putusan Nomor 607/Pdt.G/2013/ Pn.Mdn) Jurnal Ilmiah Penegakan Hukum, 3 (2) 2016: 114- 120

Maryanto, (1996),“Tinjauan Perjanjian Kredit pada Bank Pembangunan Daerah Sumatra Barat Cabang Simpang Empat", S1 Fakultas Ilmu Hukum Yayasan Pendidikan Pasaman, Lubuk sikaping

Pasaribu, E.M. Minin, D. Marlina \& Ramadhan, M.C. (2019). Analisis Hukum Terhadap Benda Jaminan Fidusia Yang Digadaikan Oleh Debitur Kepada Pihak Lain. ARBITER: Jurnal Ilmiah Magister Hukum, 1(1) 2019: 53-65.

Simanjuntak. N. (2009). Acara Pidana Indonesia Dalam Sirkus Hukum, Jakarta: Ghalia.

Sipayung, I.M. Kamello, T. Marlina \& Kartika, A. (2019). Perjanjian Jaminan Fidusia Kaitan dengan Penyidikan Tindak Pidana Perlindungan Konsumen. ARBITER: Jurnal Ilmiah Magister Hukum. 1(2): 157-166.

Siregar, R.J., Barus, U.M. \& Siregar, T. (2020). Analisis Yuridis Kewenangan Penyitaan Harta Kekayaan Wajib Pajak Oleh Juru Sita Pajak (Studi Di Kantor Pelayanan Pajak Pratama Medan Timur). ARBITER: Jurnal Ilmiah Magister Hukum. 2(1) 2020: 74-86

Subekti, R, (1979). Pokok-Pokok Perdata, PT. Intermasa, Jakarta.

Syamsuddin, M.S. (2005)., Perjanjian-Perjanjian Dalam Hubungan Industrial. (Jakarta : Sarana Bhakti Parsada.

Widjaja, E., \& Putra, W. (2019). Karakteristik Hak Kebendaan Pada Objek Jaminan Fidusia Berupa Benda Persediaan. JURNAL MERCATORIA, doi:https://doi.org/10.31289/mercatoria.v12i1.2316

Yahya, M. (2006). Ruang Lingkup Permasalahan Eksekusi Bidang Perdata, Jakarta, Sinar Grafika, 2006. 